Палій К. А., головний спеціаліст

Наџіональна комісія з цінних паперів та фондового ринку м. Київ, Україна

DOI: https://doi.org/10.30525/978-9934-26-036-0-12

\title{
УПРАВЛІННЯ РЕАЛЬНИМИ ІНВЕСТИЦІЯМИ
}

Необхідною умовою розвитку будь-якого підприємства як суб'єкта підприємницької діяльності є наявність інвестицій. Формування інвестиційних ресурсів на підприємстві створює основу для фінансування необоротних та оборотних активів. Активізація інвестиційної політики на підприємстві забезпечує 
умови для використання сучасної матеріально-технічної бази, створюються можливості для впровадження у виробництво інноваційних розробок, підвищуються конкурентні позиції суб'єкта господарювання на ринку.

Відповідно до Закону України «Про інвестиційну діяльність» Інвестиціями $\epsilon$ всі види майнових та інтелектуальних цінностей, що вкладаються в об'єкти підприємницької та інших видів діяльності, в результаті якої створюється прибуток (доход) та/або досягається соціальний та екологічний ефект. Такими цінностями можуть бути: кошти, цільові банківські вклади, паї, акції та інші цінні папери (крім векселів); рухоме та нерухоме майно (будинки, споруди, устаткування та інші матеріальні цінності); майнові права інтелектуальної власності; сукупність технічних, технологічних, комерційних та інших знань, оформлених у вигляді технічної документації, навиків та виробничого досвіду, необхідних для організації того чи іншого виду виробництва, але не запатентованих («ноу-хау»); права користування землею, водою, ресурсами, будинками, спорудами, обладнанням, а також інші майнові права; інші цінності [1].

Основа інвестиційної діяльності підприємства формується завдяки реальному інвестуванню. Потреба у реальних інвестиціях визначається відповідно до цілей та завдань, які ставляться перед підприємством. Використання реальних інвестицій забезпечує відтворення основних засобів на простій та розширеній основі, тобто створюється матеріальний фундамент розвитку підприємства.

Реальні інвестиції можна визначити, як вкладання капіталу в основні та оборотні фонди, 3 метою створення нового а/або відновлення існуючого капіталу.

Відповідно до особливостей та специфіки інвестиційної діяльності підприємств, прийнято виділяти три основні форми реальних інвестицій:

1) капітальні інвестиції (дана форма реальних інвестицій реалізується через вкладання усіх форм капіталу у відтворення 
основних фондів, зокрема будівлі, споруди, автомобільний транспорт, прилади та інструменти, обладнання та ін.);

2) інноваційні інвестиції (реалізується шляхом вкладання усіх видів капіталу у нематеріальні активи підприємства, для використання в діяльності підприємства новітніх наукових i технологічних рішень (знань), які ще можна представити як інтелектуальні інвестиції);

3) інвестиції у матеріальні оборотні активи (реалізуються через вкладання усіх форм капіталу, для збільшення запасів матеріальних оборотних активів підприємства, для розвитку основних та оборотних активів даного підприємства).

Управління інвестиціями включає: з'ясування сутності і форм інвестицій, класифікацію інвестицій підприємства, управління реальними інвестиціями, управління джерелами фінансування капітальних вкладень, управління фінансовими інвестиціями, визначення методів оцінки ефективності окремих фінансових інструментів інвестування, управління формуванням портфеля фінансових інвестицій [3, с. 136].

Управління реальними інвестиціями підприємства представляє собою систему принципів та методів підготовки, оцінки й реалізації найбільш ефективних реальних інвестиційних проектів, спрямованих на реалізацію інвестиційних цілей. Основні етапи здійснення фінансового управління реальними інвестиціями відображено на рис. 1 [4, с. 165].

Отже, функціонування та розвиток будь-якого підприємства потребує ефективного управління реальними інвестиціями. Оптимальне співвідношення структури основного капіталу на підприємстві забезпечує необхідні умови для здійснення операційної діяльності суб'єкта господарювання. Реалізація інвестиційних проектів на підприємстві створює необхідні передумови щодо впровадження прогресивних, ресурсозаощаджувальних технологій 3 поступовим переходом на інноваційну модель господарювання. 
Метою управління реальними інвестиціями $є$ оцінка найефективніших реальних інвестиційних проектів і забезпечення реалізації окремих інвестиційних програм.

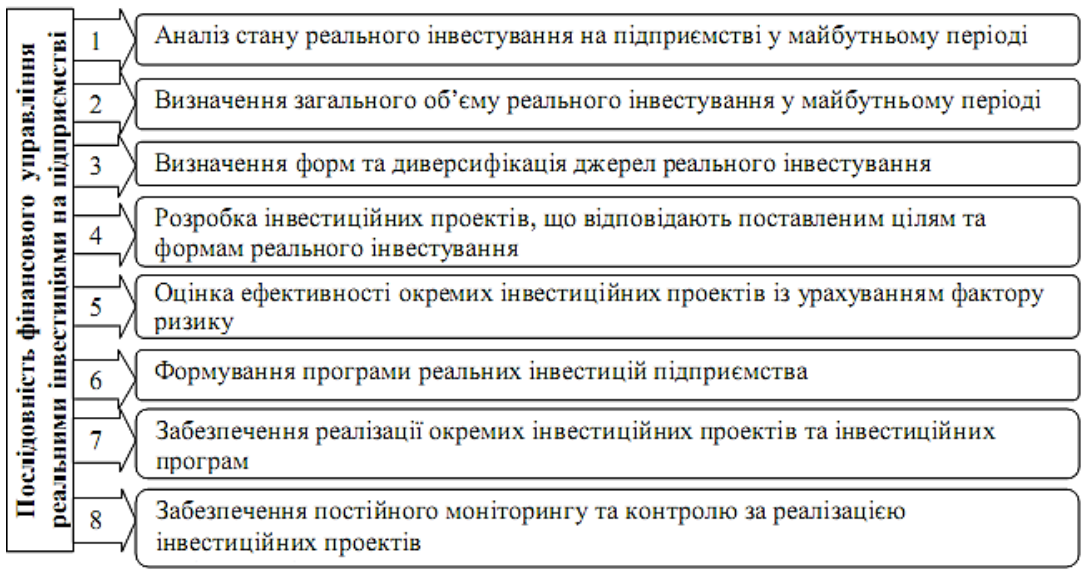

\section{Рис. 1. Етапи фінансового управління реальними інвестиціями на підприємстві}

Одним із ключових етапів управління реальними інвестиційними проектами $\epsilon$ оцінка їх ефективності. Доцільно висвітлити дві групи методів: дисконтні методи розрахунку та статистичні (бухгалтерські) методи розрахунку (рис. 2) [4, с. 169].

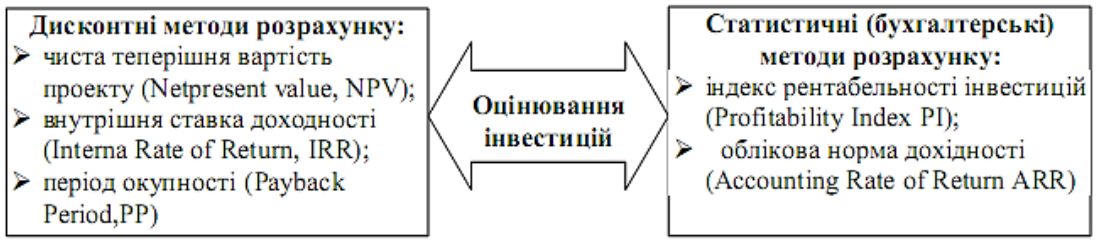

\section{Рис. 2. Методи оцінювання ефективності реальних інвестицій}

Дисконтні методи розрахунку використовуються при обов'язковому дисконтуванні інвестиційних витрат та доходів за окремими інтервалами досліджуваного періоду. Такі методи розрахунку ще називаються динамічними, тобто які визнача- 
ються на основі значень результатів протягом всього строку реалізації проекту. Всі динамічні показники враховують фактор впливу часу. При їх розрахунку використовується техніка дисконтування. Важливим етапом цього методу $\epsilon$ визначення ставки дисконту.

На основі даних методів розраховуються наступні показники: чиста теперішня вартість проекту (netpresent value, NPV); внутрішня ставка доходності (Internal Rate of Return, IRR); період окупності дисконтований (Payback Period, PP).

Статистичні (облікові) методи розрахунку передбачають використання у розрахунках даних щодо інвестиційних витрат та доходів без їх дисконтування у часі. У статичних методах за основні критерії беруть такі показники, як: витрати, дохід, прибуток, рентабельність та ін. Розмір витрат обчислюється для кожної альтернативи інвестування, як середнє значення упродовж усього планового періоду. При цьому для деяких видів витрат необхідно враховувати їх залежність від майбутнього обсягу виробництва. Сума всіх складових витрат дає розмір витрат для кожної альтернативи. На основі даних методів розраховуються наступні показники: індекс рентабельності інвестицій (ProfitabilityIndex PI); облікова норми дохідності (Accounting Rate of ReturnARR).

Bci розглянуті вище показники знаходяться між собою в тісному взаємозв'язку. Тому при оцінці ефективності реальних інвестицій їх слід розглядати в комплексі. Кінцевий відбір інвестиційних проектів у портфель, що формується, здійснюється з врахуванням взаємозв'язку всіх і розглянутих критеріїв. Якщо той чи інший критерій $€$ пріоритетною ціллю формування портфелю (висока ефективність, низький рівень фінансових ризиків тощо), то необхідність у подальшій оптимізації портфелю реальних інвестицій не виникає. Якщо ж передбачається збалансованість окремих цілей інвестування, то портфель оптимізується за критерієм дохідності та ризиків або дохідності та ліквідності. 


\section{Лiтература:}

1. Закон України «Про інвестиційну діяльність»: закон України від 18 верес. 1991 p. № 1560-XII [із змінами станом на 13.02.2021 p.]. URL: https://zakon.rada.gov.ua/laws/show/1560-12\#Text.

2. Бланк І.А. Фінансовий менеджмент: підруч. Київ : Ельга, Ніка-Центр, 2010. $656 \mathrm{c}$.

3. Васьківська К.В., Сич О.А. Фінансовий менеджмент : навч. посіб. Львів : «ГАЛИЧ-ПРЕС», 2017. 236 с.

4. Фінансовий менеджмент : підручник / Д.І. Дема, Л.М. Дорохова, О.М. Віленчук та ін. Житомир : ЖНАЕУ, 2018. 320 с. 